\title{
Governmental Accountability, National Development and the Ombudsman: A Commonwealth Perspective
}

fohn Hatchard ${ }^{\star}$

The recent rapid and dramatic political changes in many countries have led to renewed calls for action to strengthen governmental accountability and to stimulate economic development. This applies particularly to developing nations. Thus at the April 1990 Bretton Woods Committee meeting, the World Bank president listed better governance as the primary requirement for economic recovery in Africa. This is reflected in the World Bank's blueprint for Africa entitled Sub-Saharan Africa: From Crisis to Sustainable Growth which highlights the need for accountability, participation and consensus building in order to achieve successful development. The leverage available to the West to induce such change is based upon the policy of political conditionality. This provides rewards in the form of economic and technical aid to democratic governments and to those which are seeking to introduce greater accountability and democracy. The corollary is that countries which are particularly bad cases of repression and abuses of human rights are penalised. As the British Foreign Secretary has stated, Britain will favour "countries tending towards pluralism, public accountability, respect for the rule of law, human rights and market principles". ${ }^{1}$ Of course, such a policy has always been present in relations between the West and developing nations. What is new is the explicitness of political conditionality and its extension beyond the issues of friendly relations and human rights to that of democratization.

Accountability is a central feature of this policy because arguably it leads to more open government and makes it more difficult for states to conceal human rights abuses. ${ }^{2}$ This means that there is a need for developing nations, in particular, to implement effective mechanisms of governmental accountability. The object of this article is to suggest that the office of the ombudsman can play a

* Senior Lecturer in Law, University of Buckingham.

1. Douglas Hurd, "Promoting Good Government" in Crossbow Autumn 1990, p. 4. The principle of linking aid to "good government" is perhaps debatable but has been recognised by the European Community, the USA and the United Kingdom. For a full discussion see K. Tomasevski, "Human Rights Violations and Development Aid: From Politics Towards Policy", Commonwealth Secretariat, 1990.

2. See Hurd, ibid., p. 5. 
key role in this respect. ${ }^{3}$ It is also argued that certain common features are necessary if the institution is to make an effective contribution towards governmental accountability and national development in developing nations. The discussion focuses on the results of a study of the operation of the office of the ombudsman in 17 developing nations in the Commonwealth. ${ }^{4}$ This was carried out by the author in 1991 as part of a Commonwealth-wide study of statutory human rights bodies on behalf of the Commonwealth Secretariat Human Rights Unit. It involved an analysis of replies to a detailed questionnaire which was sent to all ombudsmen in the participating countries together with information gleaned from their Annual Reports.

\section{The Office of Ombudsman}

The aim of the office of ombudsman is well-known. ${ }^{5}$ It is the pursuit of administrative justice in a manner which is confidential, informal and flexible. Thus any person who claims to have suffered injustice at the hands of a government official may complain to the ombudsman free of charge. If the case is accepted, an investigation is undertaken in private. As a permanent, independent, statutory (and often constitutionally established) institution, the office is potentially a most effective investigatory body operating within - although not being a part of - government. This is because wide-ranging investigative powers give an ombudsman unique access to government documents and officials and allows for the development of personal contacts with high-ranking government officials which can often swiftly resolve a complaint.

\section{The Development of the Ombudsman in the Commonwealth}

In 1962 New Zealand became the first Commonwealth country to establish an office of the ombudsman and as a result of its success an "ombudsman explosion" occurred. ${ }^{6}$ In 1966 Tanzania became the first African country to establish the institution under the name of the Permanent Commission of Enquiry (PCE). In Ghana, the 1969 Constitution created the office but due to the later overthrow of the government, it was not until the passing of the Ombudsman Act in 1980 that it actually became operational. Other Commonwealth African countries to establish the office are Mauritius (1968), Zambia (1974), Nigeria (1975), Zimbabwe (1980),

3. It should be noted that the terminology varies from country to country but for the sake of consistency, the term "ombudsman" is used throughout this article.

4. These are: Barbados; Ghana, Guyana; India; Jamaica; Mauritius; Namibia; Nigeria; Pakistan; Papua New Guinea; St Lucia; Solomon Islands; Swaziland; Tanzania; Uganda; Zambia; Zimbabwe. 5. I was somewhat troubled by the gender connotation of the word and considered using either "ombudsperson" or "ombuds". I was informed that most words in Swedish are in the neuter gender and thus "ombudsman" can be either male or female. In any case, the word "man" cannot be simply dropped or replaced as it would change the meaning altogether.

6. Sir Guy Powles, a former Chief Ombudsman for New Zealand, has noted that people got to like Ombudsmen and found them useful in dealing with Professor Wade's "powerful engines of authority": see G. Powles, "Citizen's hope: Ombudsmen for the 1980s", 5 Commonwealth Law Bulletin 522 , at p. 523. 
Uganda (1986) and Namibia (1990). The Office of the Ombudsman in Swaziland represents the sole casualty in the Commonwealth. It was established in 1983 but in 1987 was scrapped by the government. As is seen later, the reasons for its demise are important as they illustrate how not to organise and run the institution.

In 1966 Guyana became the first Caribbean nation to establish the office. It was followed by Trinidad and Tobago (1976), Jamaica (1978), St Lucia (1979) and Barbados (1981). In the Pacific region, an office was established in Papua New Guinea in 1975. The Solomon Islands (1980) and Western Samoa (1988) then followed suit. On the Indian sub-continent, the office of the Wafaqi Mohtasib (Ombudsman) was established in Pakistan in 1983 whilst the Lokayukta, i.e. "peoples' procurator", was first established in Maharashtra State in India in 1971 and now operates in twelve Indian states."

Thus the office of the ombudsman is firmly established in many developing nations of the Commonwealth. It has proved to be extremely adaptable and operates in multi-party and one-party states, in states under military rule and in societies with radically different religious and ethnic backgrounds. Its potential importance to developing nations was noted by the Presidential Commission on the Establishment of a One Party State in Tanzania:

"In a rapidly developing country, it is inevitable that many officials, both of Government and of the ruling party, should be authorised to exercise wide discretionary powers. Decisions taken by such officials can, however, have the most serious consequences for the individual, and the Commission is aware that there is already a good deal of public concern about the danger of abuse of power. We have, therefore, given careful thought to the possibility of providing some safeguards for the ordinary citizen."

The result was the establishment of the PCE.

Professor S. A. de Smith has rightly pointed out that, "an ombudsman cannot be bought off the peg: he must be made to measure." 8 Thus the institution has developed somewhat differently in individual Commonwealth jurisdictions. However, it is argued that there are five fundamental elements required for an effective office: (1) an independent office; (2) accessibility for all members of the public; (3) an adequate jurisdiction; (4) adequate investigatory powers; (5) effective remedial powers. Each of these elements is now critically examined.

\section{An independent office}

As a former Commonwealth ombudsman has rightly stated: "I do not think that it

7. See B. K. Gupta, “A Balance-sheet of State Lokayuktas", (1984) 26 fo. Int. Law Inst., 122, 123. As yet there is no national ombudsman in India although its establishment has been sought for some years. The Constitutions of Antigua and Barbuda; Bangladesh; Dominica; and the Turks and Caicos Islands also provide for an ombudsman although, to date, none have been established.

8. Mauritius Legislative Assembly Sessional Paper No. 2 of 1965, para. 39. 
is an overstatement to say that an Ombudsman's office not properly budgeted, not properly staffed, . . . and not properly backed by those who brought it into being, amounts to nothing more than a front and a facade."9 In this section, the challenge of establishing and maintaining an independent office is considered:

\section{(a) Appointment process}

In an effort to avoid undue executive influence, the original concept of the institution was that the ombudsman would be appointed by or on the recommendation of the legislature. ${ }^{10}$ Significantly, the jurisdictions in the study have largely opted to exclude or curtail such involvement. Thus in countries such as Pakistan, Uganda, Mauritius and Tanzania the appointment remains the sole responsibility of the head of state whilst in Zambia, Namibia and Zimbabwe the President is merely required to consult with or to act on the recommendation of a Judicial Service Commission. "Several Caribbean nations do retain some links with the legislature. Thus in St Lucia and Trinidad and Tobago the appointment is made by the head of state after consulting with the Prime Minister and Leader of the Opposition whilst in Guyana the appointment is made by the President acting after consultation with the Minority Leader. However, even here there is no obligation on the head of state to follow any advice. There are several possible explanations as to why the legislature has ceased to play the major role in the appointment process. One is that by its very nature the work of the ombudsman gives him/her access to politically sensitive information. Thus in relatively young and politically immature nations it is important that the appointee is politically acceptable to the head of state. In addition, the influence and prestige of the legislature in many developing countries is somewhat limited. Accordingly, unless the ombudsman is seen to have the blessing of the head of state, it may be very difficult for him/her to get the necessary cooperation from government officials.

Whatever the merits of such arguments, it seems inevitable that executive involvement in the appointment process will continue. The task then is to seek an appointment procedure which will, as far as possible, still produce a suitable candidate. Perhaps the most attractive approach is that of Papua New Guinea where the appointment is made by the President acting in accordance with the advice of a specially constituted Ombudsman Appointments Committee. This body is made up of members of the judiciary, public service and parliament (including the leader of the opposition). Similarly, the ombudsman in the Solomon Islands is appointed by the Governor-General acting in accordance with

9. Mr Arthur Maloney, QC quoted in the 5th Annual Report of the Ombudsman of Trinidad and Tobago, p. 3.

10. In Scandinavian countries, the ombudsman is elected by parliament itself. In New Zealand, Canada, Australia, the United Kingdom and Hong Kong appointments are made on the recommendation of their respective legislatures.

11. In practice, the traditionally strong executive influence over such commissions hardly points to a demonstrably independent appointment process. 
the advice of a special committee comprising the Speaker of the legislature, Chairman of the Public Service Commission and Chairman of the Judicial and Legal Service Commission. The committee in Papua New Guinea is rightly viewed as "an ingenious device entrenched in the Constitution not only to prevent possible abuse by the Government in power regarding these important appointments but also to make sure that the members of the Ombudsman Commission are politically neutral and persons of high integrity and standing." 12 This encapsulates the essence of the appointment process, for without these characteristics the office is unlikely to gain the confidence of the public.

\section{(b) Qualifications for appointment}

The study revealed a variety of views concerning eligibility for appointment as an ombudsman. In some jurisdictions there are specific qualifications for the post with the most common being that the incumbent must have legal qualifications. This is the position in Ghana, Namibia, Zambia and some Indian States. In others, experienced public servants are required. For example, in Uganda, a person is qualified for appointment as Inspector-General of Government (IGG) when he/she has served in a field of discipline relevant to the work of the office for not less than seven years. In Zimbabwe the qualifications for appointment are excessively wide. The incumbent must either have legal qualifications, or have been a Permanent Secretary of a Ministry or a regional magistrate or in the opinion of the President "be a person of ability and experience and distinguished in the public life of Zimbabwe." In contrast, several other jurisdictions place the emphasis solely on the calibre of appointee. For example, in Nigeria the key criterion is "a high standard of integrity and probity exhibited in previous offices held", whilst in Papua New Guinea the Chief Ombudsman must be, in the opinion of the appointing committee, "a person of integrity, independence of mind, resolution and high standing in the community." 13 Whether specific qualifications are necessary is debatable for it is clear that the real need is to appoint a demonstrably independent and able individual, i.e., it is who not what the appointee is that is important. Even so, in practice, most offices in the study reported that the majority of the past and present incumbents were either former judges or held legal qualifications.

\section{(c) Term of office}

In most countries in the study the ombudsman has a fixed term appointment ranging from three years (e.g., Nigeria and Tanzania) to six years (e.g., Papua New Guinea). ${ }^{14}$ Almost invariably the appointment is renewable, in most cases at the sole behest of the head of state. Exceptionally, in Pakistan the Wafagi Mohtasib

12. See Quarterly Newsletter of the Ombudsman Commission of Papua New Guinea, vol. 1, p. 6.

13. Organic Law on the Ombudsman Commission, s.4(1).

14. This is only in the case of a citizen. A non-citizen holds office for three years only. 
(Ombudsman) is eligible to serve just one four year term. ${ }^{15}$

It is not clear as to why such restrictions are imposed for arguably, a constant change of office-holder(s) potentially undermines the effectiveness of the office. This was recognised in Zambia where the Commission for Investigations consists of the Investigator-General and three commissioners. Originally the latter served for three years and were then automatically replaced. This was found to be unsatisfactory because commissioners were required to relinquish office just when they had learnt enough and were able to give of their best. As a result, a 1986 constitutional amendment now permits a commissioner to serve continuously for up to six years. ${ }^{16}$

The need for an ombudsman to develop solid links and "informal channels of communication" with the bureaucracy is invaluable if he/she is to be effective. This takes time and patience and arguably a more permanent appointment is warranted. This is rightly reflected in those jurisdictions which provide for a more permanent career structure. Thus the ombudsman in Ghana and Namibia together with the Investigator-General in Zambia all hold office up to the age of 65 years. ${ }^{17}$ Such a system is worthy of consideration by other states.

\section{(d) Removal}

In most jurisdictions in the study the grounds and procedure for removal were similar to those pertaining to members of the judiciary. Thus an incumbent is only removable for inability to perform the duties of office by reason of physical or mental incapacity or misconduct/misbehaviour. In the Solomon Islands, Ghana and Namibia the removal procedure is the same as that for a judge. In other countries, such as Trinidad and Tobago, St Lucia, Zimbabwe and Mauritius, the head of state must act on the advice of a specially constituted tribunal. ${ }^{18}$ Exceptionally, some jurisdictions require a complex procedure involving all branches of government. For example, in Zambia, following the passing of a resolution by the National Assembly to investigate the possible removal of the Investigator-General, the Chief Justice must appoint a tribunal of enquiry. If such tribunal so advises, the President must remove the Investigator-General from office. Similarly, in some Indian states, the removal of the Lokayukta requires the holding of a formal judicial enquiry followed by the approval of each House of the State Legislature. One unusual variant on the removal procedure is in Pakistan where the President may unilaterally remove the Mohtasib from office on specified grounds. In response, the Mohtasib may "if he sees fit and appropriate to refute any charges" request an open public evidentiary hearing before the Supreme

15. In Uganda no term of office is specified for the Inspector-General of Government but proposed amendments to the enabling Act will probably specify a definite term.

16. Constitution of Zambia (Amendment) Act 1986.

17. Indeed, in Namibia the President may extend the retiring age of any Ombudsman to 70 years.

18. In Uganda the present law is silent on the matter but proposed amendments will provide a similar removal process. 
Judicial Council. If this does not take place within a specified period, the Mohtasib is "absolved of any and all stigma whatever". ${ }^{19}$ There are two jurisdictions which have quite unsatisfactory provisions. In Tanzania the President, acting in his sole discretion, may remove the ombudsman without giving any reasons. ${ }^{20}$ In Nigeria the incumbent is either removed or is "requested" to withdraw by the Armed Forces Ruling Council "for conduct prejudicial to the good name of the office" following a report by the Chief Commissioner. Such provisions give an incumbent no protection whatever from arbitrary removal and are always liable to be abused.

It is important that the tenure provisions for an ombudsman are satisfactory because of the ever present danger of political pressures being brought to bear on $\mathrm{him} / \mathrm{her}$ during an investigation. Perhaps as a sign of the calibre of appointees, on only one occasion has an ombudsman actually been removed from office. This was in 1988 when the Oyo State Commissioner in Nigeria was removed following a report by the Chief Commissioner to the Armed Forces Ruling Council. ${ }^{21}$ Nevertheless, a clearly articulated removal system ensures that as far as possible an incumbent is protected from arbitrary dismissal.

\section{(e) Funding and staffing}

The provision of an independent budget is essential in order to maintain the confidence of the public. This point is highlighted in the case of Zimbabwe where funding for the office (except the salary of the ombudsman) comes from the Ministry of Justice. As the ombudsman has noted, this situation tarnishes the image of the office as an independent body in the eyes of the public and causes problems when investigations are undertaken into complaints against the Ministry itself. In addition, the lack of an independent budget prevents an incumbent having control over the running and development of the office. Indeed, in his 1990 Annual Report, the Ombudsman for Barbados registered his own complaint over the apparent refusal of the government to acknowledge the independence of the office by presenting its Annual Estimates of Expenditure as a sub-head of a Ministry rather than under its own Head of Expenditure as was the case of the judiciary and legislature. The persistent failure of the Ministry of Finance to reply to the request of the ombudsman over this matter was condemned as "either a case of discourtesy in not issuing a reply or a case of refusal to acknowledge the independence of the Office as conferred by Parliament." 22 In practice, only a bare majority of ombudsman in the study controlled their own budgets and, rightly, this was widely viewed by them as being unsatisfactory. The most satisfactory arrangements are either (a) to pay the expenses of the office out of monies

19. See Establishment of the Office of Wafaqi Mohtasib (Ombudsman) Order, 1983, s.6(2).

20. The Constitution of the Turks and Caicos Islands, s.65, also provides that the ombudsman may be dismissed by the Governor-General acting in his discretion.

21. At the time of writing (August 1991) the removal of the Acting Ombudsman in Zimbabwe was also being considered by a tribunal.

22. Annual Report 1990, p. 4 
appropriated for that purpose by the legislature; or (b) to give the office an independent budget, as is the case in Pakistan.

To be effective, the office also requires adequate staffing levels. In the study, the size of offices varied considerably. For example, in Pakistan there are 37 investigating officers who are assisted by 415 supporting staff appointed by the Mohtasib. Similarly, in Nigeria there are a total of 199 investigative officers. In contrast, offices, such as those in Guyana and Mauritius are staffed by a single ombudsman plus a few supporting staff. Clearly the size of the population will help determine staffing levels, but even so, several ombudsman offices reported serious operational difficulties due to acute staff shortages. Thus the ombudsman in Zimbabwe has complained that "serious staffing inadequacies have persistently and frequently hampered the effective discharge of our role and functions."23 Similarly, in 1989 a former Ombudsman of Guyana, bemoaned the fact that in Guyana “. . . the Ombudsman's Office is understaffed and ill-equipped to deal with complaints, secondly there are no investigators so that the work devolves totally upon the shoulders of the person occupying the Office . . . Since there is no investigative staff, all work must be done through correspondence." The current incumbent has also noted that over a decade before, the first ombudsman expressed similar thoughts but to no avail. ${ }^{24}$ Perhaps this problem can help explain, at least in part, the reason why the number of complaints received by the Guyanese ombudsman dropped by over $50 \%$ between 1983 and 1989. In Trinidad and Tobago the ombudsman has also pointed out that the staff shortage in his office contravenes section 92 of the Constitution "which is clear, precise and free from ambiguity [and] states that 'The Ombudsman shall be provided with a staff adequate for the efficient discharge of his functions'." 25 Complaints over lack of adequate resources including inadequate accommodation and transportation were also frequently made.

\section{Overview}

The need for a demonstrably independent ombudsman is fundamental to the success of the office, a point neatly illustrated by the case of Swaziland. Here the incumbent also held the post of Secretary to the Liqoqo (Supreme Council of State), a position which was clearly incompatible with his position as ombudsman and one which seriously tarnished the image of the office in the eyes of the public. The failure to establish a clearly independent office contributed greatly to the eventual failure of the ombudsman there. ${ }^{26}$

Overall, the study showed that executive involvement in the office is now a fact

23. Fifth Annual Report of the Office of the Ombudsman, Zimbabwe, p. 2. Such a complaint has been a regular feature of the Annual Reports.

24. See Report of the Ombudsman 1989 (Guyana), p. 2.

25. Twelfth Annual Report of the Ombudsman of Trinidad and Tobago, p. 3 (emphasis in the original).

26. See J. Ayee, "The Ombudsman Experience in the Kingdom of Swaziland: A Comment", [1988] Verfassing und Recht in Ubersee 8, at p. 14. 
of life and that unless adequate safeguards are in place, it is liable to be turned into a meaningless facade by the executive. Even with a satisfactory appointee, the study also indicated that there remains a wide gap between the resources made available to the office and those needed to maintain efficiency. The view of the Chief Commissioner of the PCC in Nigeria that only "the will of the Ombudsman sustains him on the job"27 reflects the view of several office-holders. The clear message is that it is impractical to expect the office to be effective unless it is properly funded and staffed.

\section{Operation of the office}

The ease with which complaints can be lodged is one of the features of the office. In the study, an aggrieved person was invariably only required to make a written complaint to the ombudsman and in practice, even oral complaints were often accepted. ${ }^{28}$ All jurisdictions in the study had a time limit for receipt of complaints of one or two years from the date on which the complainant first knew of the facts which gave rise to the problem. Again the ombudsman frequently exercised his/her discretion to accept out of time complaints. ${ }^{29}$

The challenge of ensuring that the office serves all members of society was highlighted in the first Annual Report of the PCE in Tanzania which noted that only privileged individuals were obtaining significant practical benefits from the Commission. This point was echoed by the then President of Tanzania, Julius Nyerere, who noted that: "We must not forget the Permanent Commission [of Enquiry] receives complaints only from the most literate, aware or energetic and courageous of our citizens." 30 Part of the problem concerns lack of accessibility to the office. In countries where communications are difficult, there is a danger that only those living close to the office or with adequate transportation will be able to use it. This point is well illustrated by the situation in Mauritius where between 1985 and 1989 the Island of Rodrigues with a population of 37,538 produced just four complaints. As the Ombudsman of Mauritius wryly commented: "Either the population of Rodrigues is a very contented one or it is not sufficiently aware of the existence of the Ombudsman institution." A tour of the island was promised in order to make the office more accessible. ${ }^{31}$ Again, in Zimbabwe the Ombudsman has noted with regret that financial constraints have prevented any visits to the rural areas, resulting in virtually all complaints coming from those living in the capital city. ${ }^{32}$ This is in sharp contrast to other offices in the study which reported that the ombudsman made visits throughout the country. For example, the

27. 14th Annual Report Public Complaints Commission, 1989, Nigeria, p. 62.

28. E.g., where the complainant is illiterate.

29. E.g., where a complainant was previously unaware of his/her right to make a complaint.

30. J. Nyerere, Freedom and Development/Uhuru na Maendeleo: a Selection from Writings and Speeches 1968-73 (Dar es Salaam, 1973), p. 182.

31. Annual Report,'1989, p. 2.

32. See, in particular, the 6th Annual Report of 1989. 
Ombudsman in Trinidad and Tobago visits Tobago on a fortnightly basis whilst in Maharashtra State, India, the practice of holding sittings at divisional and district offices is well established. Such visits are considered extremely beneficial as they provide an opportunity for a direct dialogue with complainants and the possibility of swift redress of their grievances. Similarly, in both Tanzania and Zambia tours have helped to create more awareness of the existence of the office in the general populace and have fostered positive links with local officials. In some of the larger jurisdictions, such as Pakistan and Nigeria, the establishment of regional offices has also improved access to the office.

In an effort to assess the current situation, the study specifically sought to establish a profile of complainants. The results show that the majority of complainants were urban dwellers and mostly from cities where the office of the ombudsman was actually based. There was also some evidence of a link between increased accessibility to the office through tours by the ombudsman and the like and a rise in the number of complaints from rural dwellers. Once again, this highlights the need for an ombudsman to strive to make the institution accessible to all. More encouragingly, the majority of ombudsmen reported that the actual complainants themselves came from a cross-section of society or as one office put it "from illiterates to professors". The importance of becoming a truly national institution is illustrated by the situation in Swaziland. Here few people knew of the existence of the office and fewer still sought to utilise its services. Indeed in the three years of operation, it received just 40 complaints. As Ayee remarks: "This might suggest some disappointment with or apathy to the institution. It is therefore tempting to say that knowledge and use of the office was very much the preserve of a tiny majority, the urban and literate population." 33 This factor, together with the one noted earlier, largely contributed to the scrapping of the office. The paucity of complaints is a concern for many ombudsmen and in fact the study showed that no offices in the study received annually more than two complaints per 100,000 of the population.

\section{Overview}

On the face of it, the ease of access to the ombudsman should make the office extremely attractive to the public. The continuing low level of complaints is thus a cause for concern and clearly reflects the ongoing struggle of the offices to prove their value to the public. Even so, it must be remembered that statistics are not the sole indicator of the "effectiveness" of the office, an issue which is explored in the final section.

The wide range of backgrounds of complainants is encouraging although much still remains to be done. The urban bias in the figures remains a difficulty. This is almost certainly a legacy of the organisational problems discussed earlier. They emphasise once again that the creation and maintenance of an effective national institution requires the provision of the necessary resources.

33. Supra n. 26, at p. 14. 
In order to establish the legitimacy of the ombudsman it is imperative that members of the public and government officials are fully aware of the operations of the office. This is by no means easy in developing nations with relatively poor communications but many ombudsmen have made determined efforts to stimulate public awareness as to the role and function of the office including mounting modest advertising campaigns and seeking media coverage of reports. For example, in Zimbabwe all courts and government offices have a general information leaflet on the ombudsman written in the three national languages. In Nigeria the PCC has launched "enlightenment campaigns" involving interviews with the media, advertisements in newspapers and the provision of complaint boxes in all local government areas. Some offices have embarked on campaigns targeted at young people. In Trinidad and Tobago, for example, school leavers are frequently addressed by the ombudsman because they are perceived as an articulate group who can influence their parents and other adults and can tell them what matters are handled by the office. In addition, this group comprises prospective employees or employers who ought to be made aware of the concept of ombudsmanship. ${ }^{34}$ In 1990 an innovative idea was developed in Papua New Guinea where the Ombudsman Commission launched a quarterly newsletter. In the introduction to it the Chief Ombudsman notes that:

"As the chief watchdog of the Nation we wish to keep the People of Papua New Guinea informed through this publication of the functions and the working of the Commission highlighting its achievements and failures during each quarter and providing the reasons for any such failure where possible."

Such activity rightly recognizes that an ongoing communication programme aimed at sensitizing the public as to the role of the ombudsman contributes greatly towards the success of the office. Another potentially useful source of publicity is the annual report which each office is obliged to publish and send to the legislature. In theory these are of considerable importance because they help publicise the office to policy makers, legislators and the public; clarify general expectations of the bureaucracy in its dealings with citizens; and identify the criteria employed in testing those decisions. Whilst it is not possible to analyze such reports here, one comment is appropriate. As at June 1991 more than $50 \%$ of the offices in the study had failed to produce an annual report for 1989 or later whilst one office had produced just a single report in the past nine years. Delays in producing reports are sometimes inevitable but the negative effects that this has are enormous.

The efforts to publicise the office are laudable and have resulted in increased public awareness of the work of the office. This alone is not enough unless the

34. See Annual Report of the Ombudsman of Trinidad and Tobago 1989, p. 7. 
ombudsman is empowered to investigate those areas of government which are of most concern to complainants. As is seen in the next section, this is by no means the case.

\section{Jurisdiction}

All the ombudsmen in the study were empowered to investigate alleged cases of injustice as a result of "maladministration" by government officials. ${ }^{35}$ The term itself has no universal meaning although a useful working definition comes from Pakistan where it includes:

(i) a decision, process, recommendation, act of omission or commission which:

(a) is contrary to law, rules or regulations or is a departure from established practice or procedure, unless it is bona fide and for valid reasons: or

(b) is perverse, arbitrary or unreasonable, unjust, biased, oppressive or discriminatory; or

(c) is based on irrelevant grounds; or

(d) involves the existence of powers or the failure or refusal to do so for corrupt or improper motives, such as bribery, jobbery, favouritism, nepotism, and administrative excesses; and

(ii) neglect, inattention, delay, incompetence, inefficiency and ineptitude, in the administration or discharge of duties and responsibilities.

In Zambia a former Investigator-General has also given a useful list of examples of such conduct:

"The abuse of authority or maladministration ... may take various forms, for example, corruption, favouritism, bribes, tribalism, harshness, misleading a member of the public as to his rights, failing to give reasons when under a duty to do so, using powers for the wrong purposes, failing to reply to correspondence or causing unreasonable delay in doing desired public acts." 36

This flexible approach is surely right because, in the abstract, an ombudsman fills a need which other agencies and bodies are largely unable to fill, and accordingly his/her jurisdiction must be broadly construed. ${ }^{37}$ Coupled with wide investigatory powers (see infra) the scope of any investigation is potentially enormous. The study showed that there was a marked difference as to the subject matter of investigations but that in recent years some offices have expanded their

35. In practice certain key officers and authorities are frequently not subject to investigation. These invariably include the head of state and/or government and members of the Judiciary and Cabinet. 36. See Annual Report of the Commission for Investigations 1975, at p. 3.

37. This view has the powerful support of Sir Guy Powles, see n. 6 supra, p. 524. 
operations in new directions which may help lead to increased governmental accountability. Five areas are of particular interest.

(a) Human rights violations by members of the security forces

Only a bare majority of ombudsmen in the study were permitted to investigate complaints by members of the public against the security forces. ${ }^{38}$ This is regrettable because not only did many offices regularly receive such complaints but also in practice these bodies are frequently responsible for some of the worst human rights violations. The two youngest offices in the Commonwealth provide excellent examples of the potential scope of this jurisdiction.

In Uganda, the IGG may conduct and inquire or order an investigation into any allegation of a violation of human rights including cases of detention or torture. In an effort to reinforce his powers, the IGG recently recruited a former highranking army officer on the basis that his personal contacts and knowledge would facilitate inquiries into complaints against members of the security forces. Assuming this is not a mere "window-dressing" exercise, the appointment may result in genuine accountability of the security forces. Similarly, in Namibia the ombudsman has the duty to investigate complaints from any inhabitant of Namibia concerning violations of fundamental rights by government officials (both national and local). ${ }^{39}$ It is significant that here the office of the ombudsman is perceived as an integral part of the constitutional structure which seeks to prevent a repeat of the widespread human rights violations perpetrated by the former South African administration.

The prohibition on investigations into security forces has been defended on the grounds that they "might have the result of inhibiting [their] activities, much to the detriment of the State". ${ }^{40}$ Such a view is unconvincing for why an investigation into complaints should "inhibit" security forces operations is only explicable on the basis that such activity was potentially unlawful and government was anxious to conceal such actions. In reality, there are several advantages of an investigation by the ombudsman into such matters. First, individuals can have their allegations fully examined by a body which has wide-ranging investigative powers including the right to inspect all relevant documents and to question all those involved. However the confidential procedure prevents the investigation turning into a potential "trial by the [Western] media". As Gering has rightly noted: "The modus operandi of the ombudsman is often more appropriate for the protection of detainees and the handling of complaints involving state security than are those of the courts." 41 Secondly, practice has shown that the ombudsman is even-handed

38. It was far more common for the ombudsmen to be able to investigate complaints by members of the security forces concerning terms and conditions of service.

39. The only "officials" specifically excluded are judges and judicial officers. Does this mean the ombudsman can investigate a complaint against the President or Prime Minister?

40. See the statement of the Zimbabwean Minister of Justice in Parliamentaty Debates, 18 June 1982. 41. R. Gering, "Legal Institutions and Human Needs", (1974) 37 Tydsk Rif Vir Hedendaagse Romeins-Hollandse Reg 274, pp. 287-89. 
in his/her consideration of cases and determines each complaint objectively. Thus a government need have no fear of a vendetta against it. Indeed the patient development of an excellent working relationship with government officials enhances the potential for the carrying out of meaningful investigations. Thirdly, the ombudsman can reinforce public confidence by an impartial and independent examination of complaints. This will reflect well on the government in that it will be seen as being prepared to protect its citizens against abuses of individual freedoms. Of course, much will depend upon the "independence" of the ombudsman himself and the extent to which government is prepared to allow him to operate in sensitive areas. However, this is a problem faced by all bodies investigating such matters. Fourthly, fear of publicity and reprisals against aggrieved persons is a very real possibility and may dissuade many from taking legal action. Further, even if a judicial determination of the matter were attempted, it is often impossible to adduce sufficient evidence to satisfy a court. The flexible and confidential investigative powers of the ombudsman overcomes such problems. In practice the ombudsmen in Zambia, Nigeria, Barbados, Ghana and Tanzania have always had jurisdiction over the activities of the security forces..$^{42}$ Although some of these countries have experienced acute security problems, there is no indication that this jurisdiction has led to any security violations or excessive number of complaints. The importance of such a jurisdiction is illustrated by the fact that in Zambia, for example, complaints against the security forces (including the police) have sometimes accounted for over $25 \%$ of all complaints. ${ }^{43}$ Perhaps the Constitutional Commission in Ghana expressed the point best when it noted that the inclusion of the security forces was "because the Constitution ... contemplates a State in which the democratic rights of every citizen are legally guaranteed and protected." 44 Without the ombudsman, many would not be able to exercise those rights.

\section{(b) Investigating corruption}

Corrupt practices by government officials hinder development and victimize persons both individually and collectively. It is a cancer which affects many

42. There was some confusion over the exact terms of the legislation in Nigeria with the Chief Public Complaints Commissioner stating in 1977 that the commission was not empowered to entertain complaints against the security forces: see A. Sule, "The Nigerian Public Complaints Commission", (1977) 3 Commonwealth Law Bulletin 312, at p. 316. However, Akanle has convincingly demonstrated that this approach was the result of an incorrect reading of the relevant legislation: see $O$. Akanle, "Self-Restraint or Abdication? A Note on the Investigatory Powers of the Nigerian Public Complaints Commissioner", (1978) 10 Zambia Law fo. 70, at p. 73.

43. On one occasion, a senior police officer in the Zambia Police Force demanded free entrance to a dance at a restaurant for himself and his six companions. This was refused and he accordingly sent members of the National Police Force to stop the dance and close the restaurant. The investigation concluded that there had been a very serious abuse of authority and the President directed that the officer be dismissed from the Force: Case 216/75, Annual Report of the Commission for Investigations 1975.

44. Proposal of the Constitutional Commission for a Constitution for Ghana to the Members of the Constituent Assembly, 1968, No. 495. 
developing nations and, as the National Resistance Movement Government in Uganda has rightly noted, throughout Africa there is a "problem of corruption, particularly bribery and misuse of office to serve personal interests." 45 The seriousness of the problem has led the United Nations Economic and Social Council to seek administrative and regulatory mechanisms to eliminate such practices. ${ }^{46}$ One such mechanism is to make use of the ombudsman. The study showed that the ombudsman in ten jurisdictions can investigate corrupt practices by government officials. For example, in Uganda the IGG is charged with combating corruption by, inter alia, examining the practice and procedures of public bodies (including parastatals) "in order to facilitate the discovery of corrupt practices and secure revision of procedures which may be conducive to [such] practices", investigating allegations of corrupt practices and fostering public support against corruption. Similarly, in Namibia the ombudsman is required to "investigate vigorously all instances of alleged or suspected corruption and the misappropriation of public monies by officials." 47

The advantage of using the office of the ombudsman here is that as a high profile "national institution" it is potentially better able to resist improper pressure from the executive than other bodies and is thus better equipped to undertake meaningful investigations. Operationally it can perform an auditing function thereby stimulating and making use of the flow of information that is essential to identifying and combating dishonesty in government. In addition, as well as being a screening point for citizen's complaints, its prestige and reputation for objectivity makes it an obvious point of contact for the reporting of wrongdoing by government officials. The confidentiality of its procedures gives the office an added advantage, particularly as this assists in countering possible intimidation of informants and complainants. In terms of cost efficiency, it is also useful to have a unified office rather than a separate anti-corruption body. In addition, some investigations are inevitably inter-related so that a unified investigatory procedure is arguably more convenient, efficient and time-saving.

Although some practical considerations may pose problems in exercising this jurisdiction to the full, ${ }^{48}$ it is essential that the terrible scourge of corruption in developing nations is tackled using every possible mechanism and in this respect the contribution of the ombudsman is potentially significant. ${ }^{49}$

45. National Resistance Movement 10-Point Plan: Point No. 7.

46. See Practical measures against corruption prepared by the Secretariat for the Eight United Nations Congress on the Prevention of Crime and Treatment of Offenders held in Havana, Cuba in August/September 1990, Document A/CONF.144/8, p. 4.

47. Section 7, Inspector-General of Government Statute and Article 90(f), Namibian Constitution respectively.

48. Particularly lack of resources to fully investigate complex cases.

49. That the ombudsman can successfully investigate corruption is illustrated by the fact that the IGG has regularly reported instances of corruption by government officials including members of the National Resistance Army. The President has acted on reports of corruption by disciplining members of the NRA and radically reshuffling the NRA leadership: see Africa Confidential Vol. 30, No. 25 and Vol. 31, No. 19. 


\section{(c) Environmental issues}

Many developing countries face serious environmental problems caused by the dumping of hazardous waste, over-exploitation of land, de-forestation, pollution and the like. Perhaps in recognition of the dangers attaching to such activities, most offices in the study may investigate such matters. In Namibia, for instance, there was concern over the over-exploitation of natural resources during the colonial period. In an attempt to prevent this recurring, the ombudsman now has the duty of investigating complaints into "the over-utilization of living natural resources, the irrational exploitation of non-renewable resources, the destruction of ecosystems and the failure to protect the beauty and character of Namibia." 50 Investigations are not apparently limited to government activities and this gives the ombudsman wide-ranging investigative powers into an area of growing importance. A useful example of the exercise of this power comes from Trinidad and Tobago. Here an investigation by the ombudsman found that emissions from a sugar factory were causing damage to health and property over a wide radius. Recommendations to abate the nuisance later led to improvements being effected to the factory.

Potentially this jurisdiction represents an important part of the work of the office. In view of both the serious consequences of pollution and the like and the large numbers of persons potentially affected thereby, it is particularly important that an ombudsman be in a position to take swift action to curb the problem.

\section{(d) Independent investigations}

The majority of people in developing countries still suffer from ignorance of their legal rights and remain extremely susceptible to governmental abuses of power. ${ }^{51}$ In addition, the transportation and communication problems discussed earlier often make it impossible for a person to lodge a complaint. Thus it is clearly unacceptable to predicate action solely upon the receiving of a complaint for an ombudsman must "not just wait for complaints to be brought to him, but must go out to unearth corruption and maladministration whether the public complains or not.".52

All bar three of the countries in the study have this power and some utilise it frequently. ${ }^{53}$ Indeed, in Trinidad and Tobago about $25 \%$ of investigations are undertaken in this manner. Frequently cases are investigated as a result of a report in the newspapers/mass media. In fact, in Maharashtra State, the Lokayukta can act even on an anonymous complaint or information gathered from any other source if he/she is prima facie satisfied that there is some substance in the

50. Article 91(d), Namibian Constitution.

51. See, e.g., the Report of the Secretary-General on the implementation of the Declaration of Basic Principles of Justice for Victims of Crime and Abuse of Power, United Nations Document E/AC.57/1990/3, 15 December 1989, paras. 5-6.

52. General Information on the Office of the Inspector-General of Government (Uganda), p. 7.

53. Zambia, Zimbabwe and Namibia. 
allegation and it is in the public interest that an investigation should be carried out. Such an approach resolves any problems over the locus standi of complainants and rightly focuses attention solely on the nature of the complaint. In practice, many ombudsmen reported that this is a useful and effective power, with several stating that it was especially useful in cases of alleged corruption or environmental hazards.

\section{(e) Encouraging systemic improvements in administration}

A power to pursue long-term investigations is potentially of considerable value because it enables the ombudsman to analyze recurring problems of administration. The only office in the survey which specifically provided for this jurisdiction was Pakistan where the Mohtasib has the power to undertake research with a view to eradicating the root causes of maladministration, and in particular corrupt practices. Elsewhere, efforts aimed at encouraging systemic improvements continue. For example, in Trinidad and Tobago, the ombudsman makes regular (and frequently unannounced) visits to custodial institutions to monitor prison administration and hear complaints from prisoners. In several annual reports the ombudsman has commented adversely on prison conditions, particularly as regards overcrowding, charges of brutality against prison personnel, lack of medical treatment and poor diet, and has called for a complete review of penal policy. ${ }^{54}$ Similarly, the ombudsman in Jamaica has sought out possible "institutionalized victims" of public maladministration by visiting prisons and childrens' homes. In view of the widely acknowledged weaknesses in the public service of many developing nations, this jurisdiction represents an extremely useful extension to the power of the ombudsman.

\section{Overview}

The precise jurisdiction of the ombudsman will inevitably vary from country to country. Even so, the office can only make a real contribution to governmental accountability if an ombudsman is permitted to investigate those issues which are of most concern to the public. The importance of this point was reflected in the fact that in some countries in the study over $40 \%$ of all complaints were rejected by the ombudsman as being "outside jurisdiction". In some cases the ombudsman was undoubtedly the inappropriate forum..$^{55}$ However many were rejected due to an unnecessarily limited jurisdiction and clearly this must be rectified in order to meet the needs of the people. This would enable the office to assist not only those who are victims of incompetent and thoughtless officials but also victims of deliberate abuses of power and the like.

In determining the scope of the jurisdiction of the office, its relationship with the courts must be considered. If its main task is that of remedying individual 
grievances caused by neglect, incompetence and the like within the bureaucracy then the institution performs a separate function to that of the courts. However, if it is also empowered to take positive action to remedy wrongs then its functions overlap those of the courts as it becomes a means of obtaining an expeditious and cheap disposition of justice. Some jurisdictions, such as Zimbabwe, seek to prevent an overlap by prohibiting the ombudsman from investigating a complaint "unless it does not appear that there is any remedy reasonably available by way of proceedings in a court." 56 This fails to take into account the lack of access to justice for many people in developing nations. The complexity of the legal process, the absence of effective legal aid schemes and/or the non-availability of lawyers invariably prevents the majority of people enforcing their legal rights. This is particularly serious as regards the protection of fundamental rights for it is trite that these are only of any real value if they are enforceable in practice. Thus, for example, the IGG in Uganda is specifically empowered to investigate complaints despite the availability of a judicial remedy where this is considered appropriate. Namibia has also adopted an innovative approach towards the protection of fundamental rights. Here the ombudsman may provide legal assistance or advice to those seeking to enforce or protect a fundamental right through the courts. ${ }^{57}$

In view of the practical difficulties faced by many people in obtaining a judicial remedy, to give the ombudsman an overlapping jurisdiction in some cases is both imaginative and appealing and is worthy of consideration in other jurisdictions.

\section{Investigations}

All the jurisdictions in the study retained the "traditional" investigative powers. Thus invariably, investigations were undertaken in private and the procedure was inquisitorial. The ombudsman may require any government official to furnish information or to produce documents relevant to the investigation and, if necessary, officials may be interviewed. In most jurisdictions the ombudsman also has the power to summon and examine witnesses at a formal inquiry and to have any witness committed for contempt. In addition, the failure on the part of any official to comply with an order of the ombudsman without reasonable cause constitutes a criminal offence. Few offices reported any use of these powers although in Papua New Guinea, a Member of Parliament and his wife were successfully prosecuted by the Ombudsman Commission in the National Court for failing to attend the Commission when summoned to do so. Both were fined.

In general, offices reported a high degree of co-operation by public servants. This is essential to the success of the institution, a fact epitomised by the experience of the defunct Swazi ombudsman who lamented that:

"Some officers have already exhibited a tendency to regard the ombudsman 
and members of staff with hostility, resentment and suspicion. The officials in question have openly spoken against the Office and some of them have already denounced its existence and advocated its abolition." 58

Several ombudsmen noted that agencies with potentially hostile clients (for example agencies with law enforcement or revenue collection functions) were more likely to react defensively to an investigation. One ombudsman suggested that one factor which produces such attitudes is that some agencies tend to become inward-looking and thus develop a corporate attitude that keeps them out of touch with contemporary administrative standards, especially external accountability. This emphasises the need for the office to undertake research on systemic improvements to enable managers to identify and rectify deficiencies in their agencies or in the programmes that they administer.

\section{Post-investigation powers}

Invariably, the ombudsmen in the study did not exercise any judicial or quasijudicial function for the incumbents had no enforcement powers and could only make recommendations to rectify an injustice. Such recommendations included: asking for a review of the procedure which led to the grievance complained of; making an ex gratia payment to make good to the complainant expenses incurred or financial loss suffered; or sending an apology to the complainant. In practice the study showed that in the majority of jurisdictions recommendations were normally followed. ${ }^{59}$ Even so, this was subject to considerable variation. Thus St Lucia, Trinidad and Tobago and Mauritius reported that virtually all recommendations were accepted by the offending bodies. In contrast, the PCC in Nigeria stated that in about $25 \%$ of cases recommendations were ignored by the offending bodies whilst in Guyana the figure was around $50 \%$.

The problem of non-compliance with recommendations raises the issue as to whether the ombudsman should have any enforcement powers. The argument against this is that the power of recommendation is fundamental to the operation of the office because it allows the ombudsman to proceed at a more informal level and manage a very much larger case load because the ultimate decision rests with the agency and not with the ombudsman. ${ }^{60}$ It is also maintained that "the inability to order change represents, paradoxically, the central strength of the office. It requires that recommendations are based on a thorough investigation of all facts, scrupulous consideration of all perspectives and vigorous analysis of all issues. Through this application of reason, the results are infinitely more powerful than those achieved through coercion." 61 These views are reflected in the study where

58. Kingdom of Swaziland Ombudsman Annual Report 1985, p. 13.

59. If a recommendation was not complied with, the matter was referred to the head of state who then determined the appropriate action (if any).

60. See, e.g., Commonwealth Ombudsman in Australia: Annual Report 1989-90, p. 3.

61. See, the Ombudsman of British Columbia Annual Report 1989, p. 17. 
the majority of ombudsmen expressly rejected the need for such powers.

Even so, in recent years several offices in the study have obtained additional powers with which to combat instances of maladministration. For example, in Namibia, the ombudsman can bring proceedings for an interdict or other suitable remedy "to secure the termination of the offending action or conduct or the abandonment or alteration of the offending procedures." 62 This provides citizens with a direct, speedy and effective protection from abuses of power by intransigent government officials. This is especially useful in cases requiring urgent action and complements the independent investigatory power. In addition the ombudsman may challenge the validity of any statutory provision if the offending action or conduct "is sought to be justified by subordinate legislation or regulation which is grossly unreasonable or otherwise ultra vires." 63 This power is of particular interest because it means that subordinate legislation becomes subject to critical review and is a safeguard which is so often missing in other developing countries. The wide-ranging investigations of the ombudsman may also uncover criminal conduct on the part of some government officials. In such circumstances the Namibian Ombudsman may refer the matter to the Prosecutor-General with a view to prosecuting the offender(s). ${ }^{64}$ The Mohtasib in Pakistan also has a useful enforcement power in that he/she may award reasonable costs and compensation to an aggrieved party for any loss or damage suffered on account of maladministration. This is recoverable from the faulty public servant or agency.

Whilst such provisions are useful they do have considerable resource implications which would prevent their wholesale use. The real solution to the problem of non-cooperation probably lies in the attitude of the executive. If a clear indication of support for the office is forthcoming, particularly from the head of state, then this will greatly enhance the status of the ombudsman and make it more difficult for officials to ignore recommendations. Without such support much of the credibility of the office is lost. For example, in Zambia, a gross abuse of authority by a junior minister led to the Commission for Investigations recommending his dismissal. The President, without giving any reasons, refused to endorse the recommendation and decided to issue a reprimand instead. ${ }^{65} \mathrm{In}$ such circumstances, it is not unreasonable for public officials to disregard unpopular recommendations, safe in the knowledge that the head of state will protect them.

In some jurisdictions the ombudsman may take action prior to making a recommendation in order to prevent officials attempting to frustrate an investigation (for example, by intimidating or harassing a complainant) or continuing an abuse of power (for example, a continuing failure to pay a salary or pension). A vivid example of the importance of this power comes from Tanzania.

62. Article 91(e) (dd), Namibian Constitution.

63. Article 91(e) (ee), Namibian Constitution.

64. This approach also has the support of the IGG in Uganda.

65. Case 89/75, Annual Report of the Commission for Investigations 1985, p. 38. 
Here a complaint was lodged with the PCE that "seven people were locked up ... The person who locked them up had no power under any law to detain anyone for more than forty-eight hours, yet the Commission received the letter of complaint after the persons had been in custody for a week. The Commission could do nothing to get them out. They continued to be in the lock-up for a long time after. Surely something must be done to remedy this." 66 Such a problem can be dealt with in Zambia, for example, for where it appears to the Commission for Investigations that any of its powers are likely to be frustrated by any person to whom the Act applies, it "may make such orders, issue such writs and give such directions as it may consider appropriate for the purpose of conducting any investigation." 67 This is an uncommon power amongst the offices of the ombudsman in the Commonwealth and, on the face of it, contradicts the essentially advisory role of the office. In fact this is not the case because the issue concerns the facilitating of an investigation rather than the enforcement of a recommendation. The problem posed in Tanzania is by no means unique and indicates that a preventative role for the ombudsman is both feasible and helpful.

\section{Assessing the Effectiveness of the Ombudsman}

The public service in many developing nations has grown bloated and inefficient and is frequently a breeding ground for nepotism, tribalism and corruption. This inevitably hinders national development. Thus Western donor countries rightly emphasise both the importance of governmental accountability and the need to develop structures designed to strengthen it. The present study has sought to examine whether the office of the ombudsman can and does play an effective role in this respect.

In theory, the unique advantages of the office of the ombudsman means it has the capacity to help improve governmental accountability. Indeed the office is potentially more significant in developing nations because of the lack of alternative avenues of redress available to the citizen. The question is whether this is achieved in practice.

There are several possible levels of analysis here. The adoption of a purely statistical approach shows that the offices in the study received remarkably few complaints and that the severe restrictions on the areas for investigation ensured that many of these are rejected for lack of jurisdiction. Curiously, the statistical data itself was viewed very differently. Thus in some jurisdictions, an increase in the number of complaints was taken as an indication of the "success" of the office and accordingly, any decline in numbers was viewed as a cause for concern. Conversely, in other jurisdictions a fall in the number of complaints was attributed to a reduction in bureaucratic inefficiency thanks to the effectiveness of the office. Given the difficulties under which many offices are currently operating, this latter 
view is surely overly optimistic. Overall, the indications are that at this level of analysis, the office of ombudsman is currently of only limited importance.

Several ombudsmen rightly asserted that it is wrong to judge the achievements of the office simply using a statistical analysis, arguing that broader tests are needed. As the Ombudsman for Barbados has noted:

"What the figures ... cannot show is the number of persons who might have become aggrieved and would have increased those figures if some of the various departments and institutions had not taken heed of the outcome of previous investigations to which they might have been subjected and subsequently improved their procedures and practices." 68

This view is echoed elsewhere and as one Chief Ombudsman has noted:

"Probably the most significant statistic providing a pointer to the effectiveness of the office is one which is not found in the report[s] and one which cannot be computed, namely, the number of potential complaints which do not reach the office simply because its existence acts as an incentive for the organisations coming within its jurisdiction to deal with matters which might otherwise be brought to our notice. It is evident . . . that some departments and local authorities have progressively modified and improved their own procedures for the handling of grievances, in some cases instituting formal review and appeal machinery for this purpose." 69

It is difficult to assess the validity of such assertions although they certainly reflect the views of several ombudsmen in the study. Inevitably, much depends upon the extent to which government officials are prepared to co-operate with the ombudsman and to implement his/her recommendations. As noted earlier, in practice, this largely hinges upon the attitude of those in the highest echelons in government towards the institution. A similar comment might be made concerning the effectiveness of independent investigations of the ombudsman.

In any assessment of the office, it should not be forgotten that it is also an important protection for government officials against unfounded, malicious or unfair attacks. Indeed the study indicated that in many cases officials were found to have acted properly. As the Ombudsman in Mauritius pointed out:

"It must not be believed that every time the ombudsman receives a complaint this means that the administration has gone wrong somewhere. The ombudsman will certainly poke his nose into the actions of the administration but he will definitely identify, after investigation, which complaints are frivolous or unjustified and reject them. He will thus act like a

68. Annual Report 1990, p. 6.

69. Report of the New Zealand Ombudsman 1979. 
shield for the administration as the investigation is done for the benefit of both the administrateur and the administre. Therefore, although the Ombudsman is often referred to as the citizen's defender, it would be wrong to call him the administration's accuser."70

Finally, the institution also plays a useful function in that it enables a person to make a complaint. Even if the complaint is not sustained, the fact that the reasons for the decision are explained is often sufficient to satisfy the individual.

Overall, one can conclude that whilst most offices are working diligently, they are facing great difficulties which prevent them realizing their full potential. It is argued that the five elements discussed earlier form an integral unit and are crucial to the development of an effective office. This means that the failure of one element inevitably undermines the effectiveness of the office. Regrettably, this is the situation in many Commonwealth countries today. Realistically, this unit can only operate with the active support of the executive. Otherwise the institution will remain a "front and a facade" and a waste of scarce resources which should be consigned to the scrapheap of history, as was the case in Swaziland.

Of course, the ombudsman is not a panacea for all governmental ills, for the relationship between the state and the individual is far too complex to be resolved by a single institution. Nevertheless, given the political will and satisfactory organisation and powers, it can play a significant role in this respect. In the new Gorbachevian era, the concept of more open government and accountability is high on the political agenda. Thus now is an opportune moment for governments to re-assess the role of the ombudsman and to take the necessary steps to promote its effectiveness. If this occurs, then the comments of the Ombudsman of Trinidad and Tobago will be applicable elsewhere:

"The Office of Ombudsman ... serves to assist the disadvantaged, the underprivileged, the poor, the weak and the frightened, who do not understand the ways of public bureaucracy. It has proved to be a useful adjunct to the courts and other tribunals in stemming human rights abuses."71

70. Annual Report 1989, p. 1.

71. Comments contained in the questionnaire. 